\title{
IN LIGHT OF SEASONAL CLIMATIC AND ANTHROPOGENIC CHANGES, IS THE VAUD CANTON (SWITZERLAND) VULNERABLE TO WATER STRESS BY THE MEDIUM-TERM?
}

\section{Dans un contexte de changements climatiques et anthropiques, le canton de Vaud (Suisse) est-il vulnérable au stress hydrique?}

\author{
Marianne Milano ${ }^{1}$, Emmanuel Reynard $^{1}$, Nina Köplin ${ }^{2,3}$, Rolf Weingartner ${ }^{2}$ \\ ${ }^{1}$ Université de Lausanne, Institut de géographie et durabilité, Bât. Géopolis, CH-1015 Lausanne, Suisse \\ marianne.milano@unil.ch,emmanuel.reynard@unil.ch \\ ${ }^{2}$ Universität Bern, Geographisches Institut, Hallerstrasse 12, Berne, Suisse \\ rolf.weingartner@,giub.unibe.ch \\ ${ }^{3}$ Swedish Meteorological and Hydrological Institute, Folkbotgsvägen 17, SE-601 76 Norrköping, Suède \\ nina.koeplin@web.de
}

\begin{abstract}
Observed changes in hydrological processes during the past 20 years in Switzerland are particularly preoccupying as they directly affect water use. In 2003 and 2011, local water shortage episodes occurred. Water withdrawals and supplies had to be restricted, notably in the Vaud canton (Western Switzerland). These droughts highlighted increasing competition among water users and new water management issues arose. This study explores how hydro-climatic conditions and water needs could evolve by the 2060 horizon and assesses the vulnerability of the canton to water stress under climatic and anthropogenic changes. Flows were simulated based on a daily semi-distributed hydrological model. Future changes were derived from Swiss climate scenarios relying on ten regional climate models. Regarding water needs, a population growth scenario was provided by the canton whereas a business-as-usual scenario was considered for irrigation and breeding trends. Currently, catchments in the canton experience moderate water stress from June to August, except in alpine areas. By the medium-term, water needs could reach more than $80 \%$ of rivers' total runoff in July and August. This should be due to higher temperatures and a higher ratio of liquid-to-solid precipitation causing more severe low flows. In addition, water needs should significantly increase from April to July, due to higher irrigation (+25\%) and urban (+40\%) water needs. This study gives a first overview of where and when water tensions are most likely to occur in the Vaud canton. Highlighting these regional differences supports the development of strategies to cope with water stress that are currently being discussed with the cantonal authorities.
\end{abstract}

\section{KEY WORDS}

Integrated modeling, water resources, water needs, climate change, anthropogenic changes, 2060 horizon, water stress, Vaud canton.

\section{RESUME}

Dans un contexte de changements climatiques et anthropiques, le canton de Vaud (Suisse) est-il vulnérable au stress hydrique?

Au cours des ces 20 dernières années, une modification des processus hydrologiques a pu être observée en Suisse. Par exemple, la limite des chutes de neiges s'est élevée de $150 \mathrm{~m}$, la fonte et le recul des glaciers se sont accélérés et les épisodes de sécheresse se sont intensifiés en été. Ces changements sont particulièrement préoccupants, d'autant plus qu'ils affectent directement la disponibilité des ressources en eau et l'approvisionnement en eau des différents usagers. En 2003 et 2011, la Suisse a dû faire face à des épisodes de pénurie d'eau au printemps et en été, provoquant des restrictions d'usages de l'eau à plusieurs reprises, notamment dans le canton de Vaud (Suisse occidentale). Ces épisodes ont révélé des compétitions accrues entre usagers ainsi que de nouveaux enjeux en matière de gestion de l'eau, tel que la définition de priorités et de taux d'allocation en eau entre les différents secteurs d'activités. Ainsi, cette

\footnotetext{
${ }^{1}$ Corresponding author: Marianne Milano
} 
étude tente d'identifier comment les conditions hydro-climatiques et les besoins en eau pourraient évoluer à l'horizon 2060 et vise à analyser la vulnérabilité du canton de Vaud au stress hydrique dans un contexte de changements climatiques et anthropiques. Les écoulements ont été simulés selon un modèle semi-distribué au pas de temps journalier. Les changements climatiques futurs proviennent de scénarios climatiques suisses construits à partir de dix modèles climatiques régionaux. Concernant l'estimation des besoins en eau, un scénario de croissance démographique fourni par le canton a été utilisé tandis que les tendances passées d'usages de l'eau pour l'irrigation et l'élevage ont été projetées à moyen terme. Actuellement, les régions alpines ne semblent subir aucun stress hydrique tandis que les bassins du Plateau suisse et de l'arc lémanique subissent un stress modéré de juin à août. A moyen terme, ce stress modéré devrait s'étendre de mai à septembre tandis que les besoins en eau pourraient atteindre $80 \%$ des ressources en eau disponibles en juillet et août. Cela devrait vraisemblablement être lié tant à des changements climatiques qu'à des changements anthropiques. Les températures devraient augmenter de $2-3^{\circ} \mathrm{C}$ au cours de l'année provoquant une plus grande quantité de précipitations sous forme liquide l'hiver et moins de fonte de neige l'été, nécessaire pour le soutien des étiages. A cela s'ajoute une hausse significative des besoins en eau d'avril à juillet, essentiellement liés à l'irrigation (+25\%) et aux besoins en eau urbains (+40\%). Concernant l'élevage, les besoins en eau devraient augmenter dans les plaines et diminuer dans les régions alpines, mais les besoins absolus devraient rester modérés comparativement aux besoins en eau urbains et d'irrigation. Cette étude fournit une première vision cantonale permettant d'identifier les bassins et les saisons où des tensions d'usages pourraient se produire à moyen terme. La mise en exergue de ces différences régionales permet ainsi de soutenir les stratégies d'adaptation actuellement en cours de réflexion par les autorités cantonales.

\section{MOTS-CLEFS}

Modélisation intégrée, ressources en eau, besoins en eau, changement climatique, changements anthropiques, horizon 2060, stress hydrique, canton de Vaud.

\section{INTRODUCTION}

During the past 20 years, significant hydro-climatic changes have been observed in Switzerland. Annual temperatures have increased by $1-1.5^{\circ} \mathrm{C}$ compared to the $1961-1990$ mean and the five warmest years occurred after 2000 [OcCC, 2008]. Increase in winter precipitation has also been noted in Northern and Western Switzerland coupled to a decrease in snowfall days [Schmidli and Frei, 2005; Serquet et al., 2011]. In addition, the snowline moved up by $150 \mathrm{~m}$, ice melt and glacier retreat sped up and summer droughts got more intense [OcCC, 2008]. These changes are particularly preoccupying as they are most likely to affect hydrological regimes and thus water supply. During the past decade, water withdrawals and supplies have already been respectively forbidden and restricted several times, notably in the Jura mountains due to lower groundwater levels, in the Lake Geneva region due to higher irrigation water needs, and in pluvial catchments of the Swiss Plateau due to lower precipitation and thus lower runoff volumes [Fündel et al., 2013]. In addition, Western Switzerland is experiencing continuing economic and demographic growth. As an example, between 2000 and 2012, the Vaud canton experienced a 10\% to 30\% demographic growth in each of its communes [FOSD-ARE, 2013]. Pressures applied on water resources are then on an upward curve. No regional investigation of current and future water stress in Western Switzerland has yet been conducted. This paper focuses on nine meso-scale catchments in the Vaud canton in order to provide an overview of the current and future pressures applied on water resources based on an assessement of the possible evolution trends of freshwater availability and needs under climatic and anthropogenic changes.

\section{STUDY AREA}

The Vaud canton is located in Western Switzerland and covers an area of $2822 \mathrm{~km}^{2}$ (Fig. 1). Nine meso-scale catchments with a surface area of at least $30 \mathrm{~km}^{2}$ and without major lake regulation were considered, covering $67 \%$ of the canton's surface area (Fig. 1). These catchments extend from the Jura Mountains (alt. max. 1677 m.a.s.1.) over the Swiss Plateau (400-600m.a.s.1) to the high alpine mountains (alt. max. 3200m.a.s.1). Climate can be described as mild and wet over the Plateau with mean annual temperatures ranging from $1{ }^{\circ} \mathrm{C}$ to $18^{\circ} \mathrm{C}$ (average over the 1984-2005 period) and precipitation varying between 70 and $100 \mathrm{~mm}$, with maxima in May and August (90-120 mm/month). In the Jura and the Alps mountains, the climate is cooler and wetter with mean annual temperatures ranging between $-3{ }^{\circ} \mathrm{C}$ and $13{ }^{\circ} \mathrm{C}$ and mean precipitation varying between $115-200 \mathrm{~mm} / \mathrm{month}$. These different climatic profiles give rise to pluvial hydrological regimes over the Plateau, nivo-pluvial regimes for rivers flowing from the Jura mountains to Lake Geneva, and transition nival to alpine nival regimes in alpine areas [Milano et al., 2015a]. Another important feature of the canton is 
its diversified anthropogenic activities (Fig. 1). Since the 1970s, the population has tripled along the shores of Lake Geneva and Lake Neuchâtel in relationship to urban and peri-urban development [FOSD-ARE, 2013]. The Vaud canton is also the second agricultural canton of the country [FSO, 2006]. Its plain and piedmont areas cover $17 \%$ of the Swiss agricultural land for which irrigation is more and more often used in order to save and ensure crop yields [MandaTerre, 2013]. Finally, climate in mountainous areas is convenient for permanent grassland thus promoting dairy cow breeding.

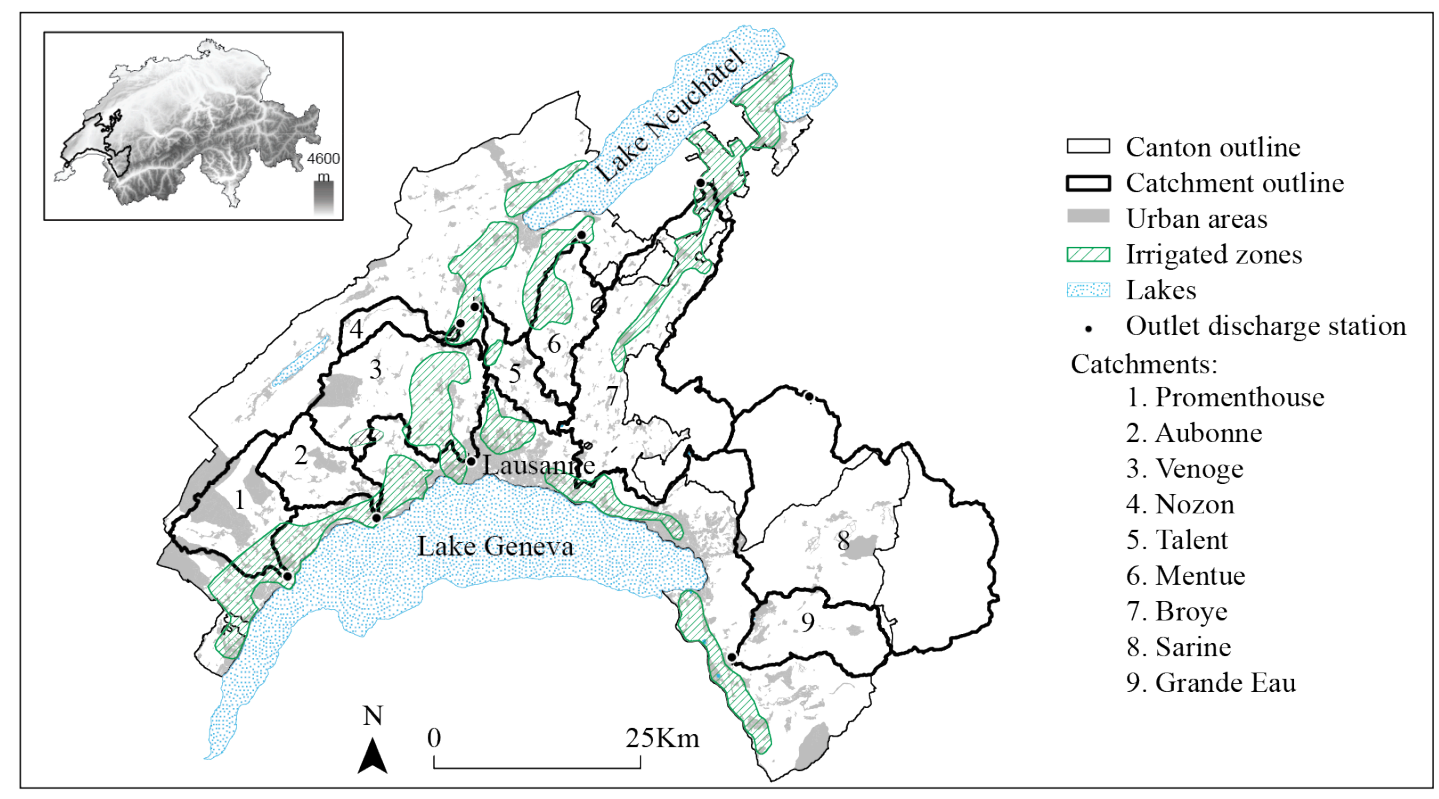

Figure 1: Main characteristics of the Vaud canton and geographical position of the 9 selected catchments.

\section{MATERIAL \& METHODS}

\subsection{An integrated approach to assess water stress}

An integrated modeling approach was set up to assess water stress under climatic and anthropogenic changes in the Vaud canton [Fig. 2; Milano et al., 2015b]. To monitor the impacts of these changes on water resources, a water stress index was used. It is based on the ratio of monthly water needs to monthly available freshwater resources [Shiklomanov, 1991]. This index expresses the intensity of anthropogenic pressures applied on river water resources. In case a water stress state is identified, it highlights that any additional water requirements might not be satisfied if other resources are not considered (e.g. pumping from groundwater or lake reservoirs).

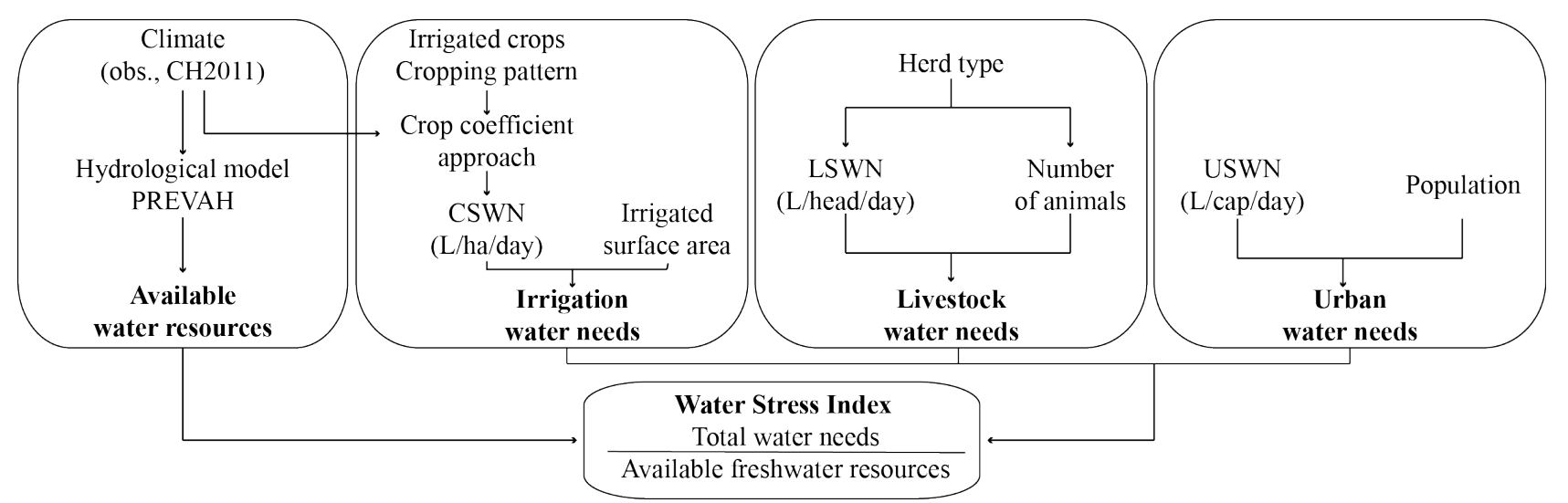

Figure 2: Methodological approach. CSWN: Crop specific water needs; LSWN: Livestock specific water needs; USWN: Urban specific water needs. 
Daily freshwater resources and water needs were estimated over the reference period 1984-2005 and the future period 2050-2071 (2060 horizon). Results were aggregated at a monthly time-step for synthesis purposes. The reference period was chosen according to climatic data availability and its coverage of both wet and dry periods [Milano et al., 2015a]. Projections of climate changes were derived from Swiss climate scenarios based on ten regional climate models forced with the IPCC A1B greenhouse gas emission scenario, and which were downscaled to the Swiss meteorological station network using the delta change method [Bosshard et al., 2011; CH2011, 2011]. Future water needs were estimated according to a business-as-usual scenario. Impacts of climate change on crops' irrigation water needs were explored but current irrigated crops and surface areas were assumed to remain unchanged. Livestock past evolution trends were carried on and a population growth scenario was provided by the canton's statistic office [Statistique Vaud, 2011].

\subsection{Freshwater resources modeling}

For each catchment, the hydrological model PREVAH was used [Viviroli et al., 2009] to simulate rivers' total runoff and evaluate seasonal changes by the medium-term. It is a semi-distributed model that relies on the HBV model structure [Bergström, 1976] to which hydrological response units (HRU) were implemented. It is process-oriented as it incorporates several modules representing the different components of the hydrological cycle. Total runoff is produced by the combination of rapid, delayed and slow runoffs simulated for each HRU at an hourly time-step. The model was calibrated over the 1993-1997 period with the aim of optimizing three statistical criteria: the volumetric deviation, and the linear and logarithmic Nash-Sutcliffe efficiency coefficients [Nash and Sutcliffe, 1970]. These criteria respectively inform on the capacity of the model to correctly represent the seasonal volumes, seasonal dynamics and dynamic of low flows. Validation was carried out over the 1984-1992 and 1998-2005 periods.

Daily meteorological data (air temperature, precipitation, relative humidity, wind speed, global radiation and relative sunshine duration) over the past reference period were collected from the automatic meteorological network of Switzerland [MeteoSwiss, 2008] and interpolated over each catchment on the basis of the detrended inverse distance weighting. Delta change signals from the CH2011 initiative [Bosshard et al., 2011; CH2011, 2011] were applied on daily temperature and precipitation series for prospective modeling. Finally, physiographical information were collected for each catchment. They were derived from Köplin et al. [2012] who acquired it from the Swiss federal statistical office [FSO, 2003].

\subsection{Estimate of irrigation, livestock and urban water needs}

Water needs were evaluated for the agricultural, livestock farming and urban sectors, the main activity sectors of the canton. Water needs were defined as the daily volume of water required for crops optimal growth, for farm animals drinking purposes, and for households, businesses connected to the communal water networks and maintenance of the communes. For each commune of each catchment, crop, livestock and urban specific water needs were first computed and were then multiplied by the communes' irrigated area, herd-heads and population, respectively (Fig. 2). Water needs of each commune were then summed to obtain estimates of total water needs for the whole considered catchment.

Daily irrigation water needs were evaluated according to the crop coefficient approach [Allen et al., 1998]. This method aims at defining the volume of freshwater necessary to meet crop evapotranspiration in addition to rainfall, based on climatic data, cropping patterns and crop growth coefficients. Daily climatic data used in the hydrological model (precipitation, potential and effective evapotranspiration) were used for both retrospective and prospective modeling in order to be consistent between freshwater and water needs estimates. Regarding irrigated crops and surface areas, for each commune, the Swiss FSO provided utilized agricultural areas [FSO, 2013a] and the MandaTerre association supplied the cultivated crops and their share of irrigated land under standard climatic conditions [MandaTerre, 2013]. Cropping patterns and crop growth coefficients were collected from the FAO [Allen et al., 1998], Aquastat [Frenken and Gillet, 2012] and Agroscope [Vullioud, 2005] databases. Based on the ten climatic scenarios, similar trends in irrigation water needs were computed by the 2060 horizon for each catchment; an average of total water needs was thus provided in the results section rather than a range of possible futures.

Daily livestock specific water needs were evaluated for each animal species identified in the communes of the canton by the Swiss FSO, who provided the number of animal heads from 1985 to 2012 on a yearly basis [FSO, 2013a]. These numbers were assumed to remain stable throughout the year. Water requirements 
for each type of herd were defined according to several literature sources [Sautier, 2004; Ward and McKauge, 2007; Collier and Lillywhite, 2011], assuming that all animals have reached adulthood and are given food with standard moisture content.

Finally, due to the limited availability of data on urban water use in each commune (only 20 communes out of 170 are documented), the national urban specific water need values, available from 1945 to 2012, were used [SGWA, 2013]. For future estimates, the per capita 2012 value was applied, assuming that progress in hydraulic efficiency would compensate possible increasing water needs related to life changes. Yearly population data was provided by the Swiss FSO from 1970 to 2012 [FSO, 2013b]. For future projections, a demographic growth scenario was provided by the canton statistical office up to the year 2040 [Statistique Vaud, 2011]. The demographic growth rate was extrapolated until 2071.

\section{RESULTS}

\subsection{Current and future water stress states}

Currently, a clear contrast between the East and West side of the canton can be identified (Fig. 3). Eastern catchments, i.e. the Mentue, Broye, Grande Eau and Sarine, do not suffer from any water stress and it should remain likewise by the 2060 horizon. In the West, catchments currently experience moderate water stress during the summer months (June, July, August). Water needs amount to $30-40 \%$ of the available freshwater (Fig. 3). This period extends from May to September over the Venoge and Talent catchments. Water stress can even be described as severe from June to August as water needs exceed $80 \%$ of the rivers' available freshwater.

By the 2060 horizon, under climatic and anthropogenic changes, pressures applied on water resources should significantly increase over all western catchments. Catchments could experience high to severe water stress from June to August, and moderate water stress in May and September (Fig. 3). The Venoge and Talent catchments should be the most vulnerable to water stress as water needs could exceed available freshwater resources from June to August (Fig. 3). This severe water stress period could even start in May over the Talent. The Venoge and Talent catchments should also experience high water stress, respectively, in May, and in April and September. These evolution are most likely due to both climatic and anthropogenic changes, which evolution are analyzed hereafter.

\subsection{Freshwater availability}

\subsubsection{Hydrological model reliability}

\begin{tabular}{|l|l|l|l|l|l|l|l|l|l|}
\hline \multirow{2}{*}{ Catchment } & \multicolumn{3}{|l|}{ Validation (1984-1992) } & \multicolumn{2}{l|}{ Calibration (1993-1997) } & \multicolumn{3}{l|}{ Validation (1998-2005) } \\
\cline { 2 - 12 } & NSE & NSE $_{\text {ln }}$ & VE & NSE & NSE $_{\text {ln }}$ & VE & NSE & NSE $_{\text {ln }}$ & VE \\
\hline 1. Promenthouse & 0.44 & 0.56 & 0.26 & 0.55 & 0.63 & 0.13 & 0.61 & 0.51 & 0.16 \\
\hline 2. Aubonne & 0.85 & 0.92 & -0.03 & 0.80 & 0.88 & -0.08 & 0.88 & 0.92 & -0.09 \\
\hline 3. Venoge & 0.89 & 0.92 & 0.02 & 0.96 & 0.95 & -0.01 & 0.92 & 0.93 & 0.00 \\
\hline 4. Nozon & - & - & - & 0.85 & 0.85 & 0.02 & 0.92 & 0.92 & -0.03 \\
\hline 5. Talent & - & - & - & 0.93 & 0.94 & -0.01 & 0.92 & 0.89 & 0.03 \\
\hline 6. Mentue & 0.90 & 0.90 & -0.02 & 0.91 & 0.85 & 0.04 & 0.95 & 0.91 & -0.06 \\
\hline 7. Broye & 0.94 & 0.94 & 0.00 & 0.96 & 0.97 & -0.01 & 0.94 & 0.94 & 0.04 \\
\hline 8. Sarine & 0.86 & 0.85 & 0.05 & 0.85 & 0.85 & -0.01 & 0.82 & 0.82 & 0.05 \\
\hline 9. Grande Eau & 0.94 & 0.94 & -0.02 & 0.87 & 0.90 & 0.01 & 0.92 & 0.91 & 0.02 \\
\hline
\end{tabular}

Table 1: Performances of the hydrological model over the calibration and validation periods.

NSE: linear Nash-Sutcliffe coefficient; $\mathrm{NSE}_{\mathrm{ln}}$ : logarithmic Nash-Sutcliffe coefficient; VE: volumetric deviation; -: no data.

The performance of the model is summarized in Table 1. Except over the Promenthouse, the seasonal and low flow dynamics are very well captured for all catchments. NSE $\left(\mathrm{NSE}_{\ln }\right)$ values range between $0.80(0.85)$ 
and $0.96(0.97)$ for the calibration period and vary between $0.85(0.82)$ and $0.94(0.94)$ for the validation periods. Seasonal volumes also correspond closely to observations with VE values ranging between $-9 \%$ and $+5 \%$ over the considered periods. The seasonal volumes and dynamics are only poorly captured over the Promenthouse. The model tends to over-estimate flows from September to March and to under-estimate flows from April to August (not shown).

\subsubsection{Freshwater resources availability under climate change}

By the 2060 horizon, temperatures are expected to rise by $2-3^{\circ} \mathrm{C}$ over the canton throughout the year and by an extra $1{ }^{\circ} \mathrm{C}$ during summer. In catchments extending from the Jura mountains to Lake Geneva, precipitation are projected to increase by $10-30 \%$ from October to May with a higher fraction of liquid to solid precipitation. During the summer months, precipitation should remain near current level. Over the Plateau and the Alps, low to no changes are projected in precipitation distribution except during summer where a 20 $30 \%$ decrease in precipitation is projected. The most pessimistic models even predict a decrease by more than half. Moreover, in the Alps, rainfall should increase over snowfall leading to less winter snow accumulation and thus to two to three times less snowmelt in spring and to none during summer.

These climatic trends should lead to significant changes in seasonal runoff. Rivers flowing from the Jura mountains to Lake Geneva (i.e. the Promenthouse, the Aubonne and the Venoge) should be affected by a 20 $70 \%$ increase in runoff from October to March with a high flow peak occurring in January instead of March or April currently (Fig. 3). Low flows should also be more severe. These catchments should then move from a nivo-pluvial to a pluvial hydrological regime due to more rainfall in autumn and winter, and less snowmelt during spring, necessary to support low flows. Over the Plateau, a 10-25\% decrease in river flows are projected throughout the year as well as more intense low flows. During summer, runoff values could decrease by $60-75 \%$ thus falling below the current variability (less than $0.5 \mathrm{~m}^{3} / \mathrm{s}$ on average; Fig. 3). In alpine areas, river flows should increase from October to February (20-50\%; Fig. 3) and decrease from March to September (30-35\%). Runoff values during low flows could fall below the current natural variability range. A shift in flows seasonality could also be observed with a maximum high flow peak in April, instead of May currently, over the Sarine (Fig. 3). Changes in precipitation distribution and snow accumulation should then induce the Grande Eau and Sarine catchments to move towards a nival and transition nival hydrological regimes, respectively.

\subsection{Possible changes in water needs}

Currently, water needs are highest in the Lake Geneva region and over the Swiss Plateau (Fig. 3). Annual values range between $7.2 \mathrm{hm}^{3} /$ year and $21.7 \mathrm{hm}^{3} /$ year. The Promenthouse, Mentue and Broye catchments are characterized by high urban water needs that represent $75-95 \%$ of their total water needs, while $70-90 \%$ of total water needs comes from irrigated agriculture in the Aubonne, Venoge and Talent catchments. In alpine catchments, total water needs are low (less than $3 \mathrm{hm}^{3} / y$ ear; Fig. 3). It is nonetheless in these catchments that livestock water needs are highest: $10 \%$ of the total water needs compared to less than $1 \%$ in other mid- to lowland catchments. Regarding the monthly distribution of water needs, it mostly follows the dynamic of irrigation water needs (Fig. 3). In general, water needs are constant from October to March and start increasing in April until reaching a maximum in July. In highly irrigated cacthments, water needs in July can reach $25 \%$ of the annual water needs.

By the 2060 horizon, highest water needs should remain in the Lake Geneva region and over the Swiss Plateau with requirements ranging between $10.6 \mathrm{hm}^{3} /$ year to $25.9 \mathrm{hm}^{3} /$ year. Increase in water needs should mostly come from the urban sector. Population should double in littoral communes, especially in those within the Promenthouse catchments, increase by $50-75 \%$ in plain areas and increase by $25-50 \%$ elsewhere. Urban water needs should then almost double in the Promenthouse $(+77 \%)$ and the Aubonne (+90\%) catchments and increase by $30-40 \%$ in other catchments. Regarding irrigation, water needs should mainly increase in the Lake Geneva region (10-20\%) and remain close to current level in other areas. Although water needs for livestock will remain low compared to other sectors (less than $0.2 \mathrm{hm}^{3} /$ year), significant changes should be noted for this sector. Livestock water needs should double to quadruple in the Lake Geneva region and be six times higher in the Plateau in line with an increase in horse and beef cow breeding. In alpine catchments, a 10-30\% decrease in livestock water needs should occur due to a decrease in dairy cow breeding. These changes in water needs should induce a $30-40 \%$ increase of monthly water 
needs over most catchments. The Aubonne, Venoge and Talent catchments should only be affected by an increase in water needs in April-May (20-30\%; Fig. 3).

(1) Promenthouse

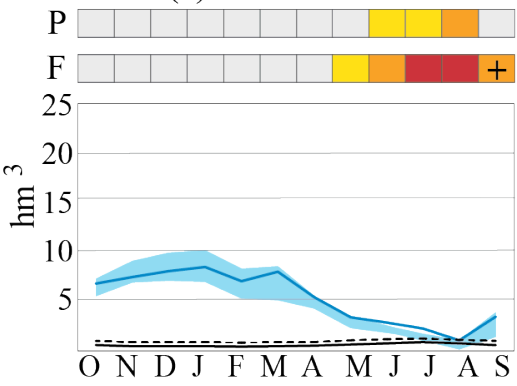

(4) Nozon

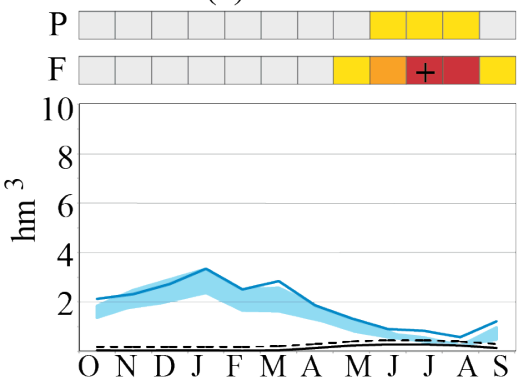

(7) Broye

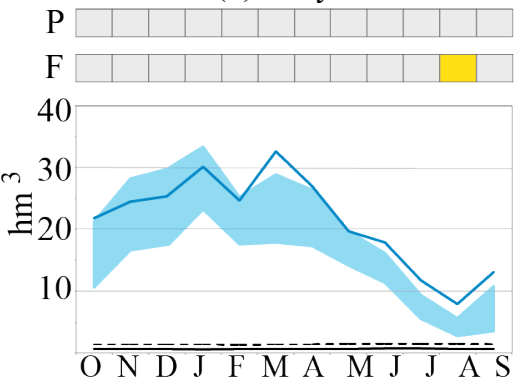

(2) Aubonne

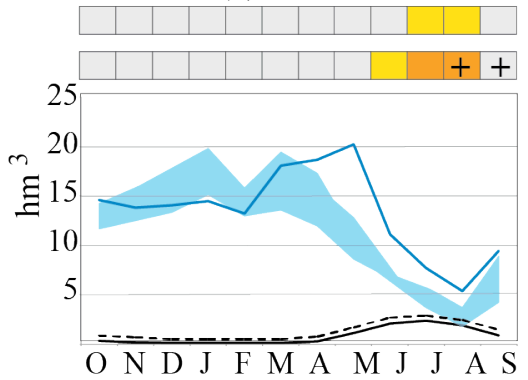

(5) Talent

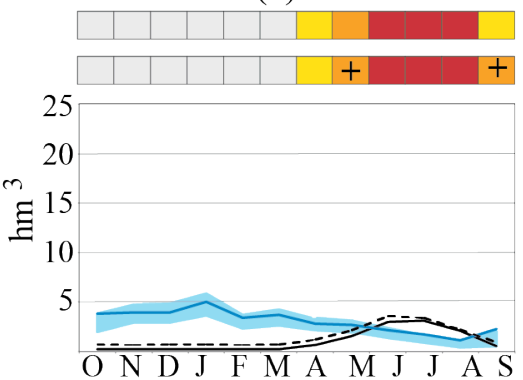

(8) Grande Eau

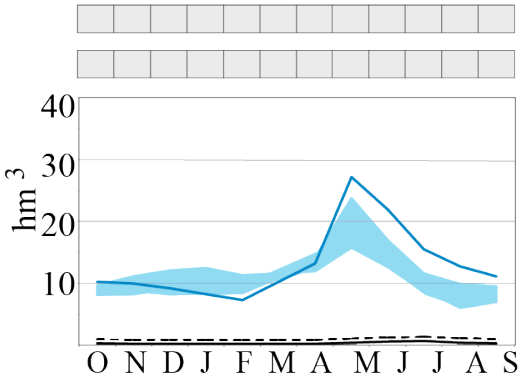

(3) Venoge

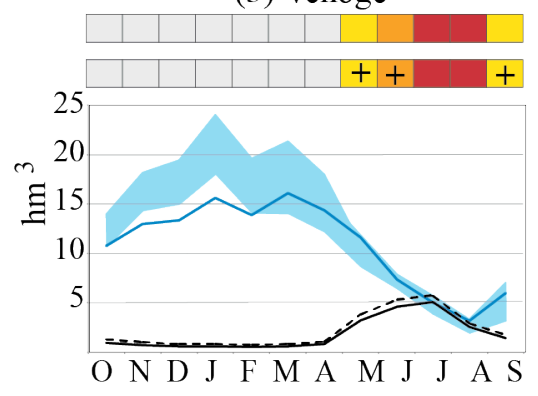

(6) Mentue

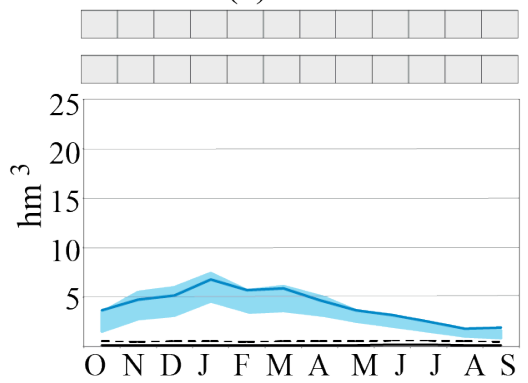

(9) Sarine

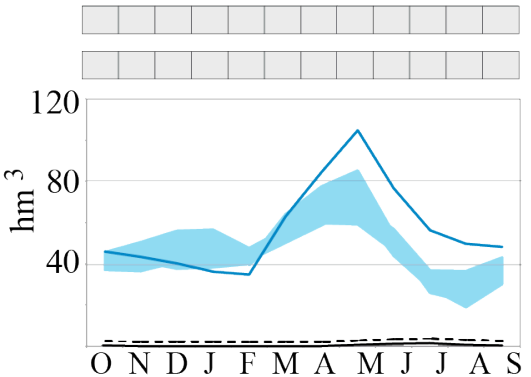

P Current water stress state

F Future water stress state

+ At least 7 models agree on the water stress state otherwise all models agree
Water stress index

$<10$ [No stress]

20 - 40 [Moderate stress]

40 - 80 [High stress]

$>80 \quad$ [Severe stress]
Freshwater resources availablity

_ Mean observation (1984-2005)

Future variability range (2050-2071)

Mean total water needs

_ Current state (1984-2005)

--.-- Future trend (2050-2071)

Figure 3: Current water stress and its evolution by the 2060 horizon in the Vaud canton in light of changes in freshwater resources availability and in total water needs.

\section{DISCUSSION \& PROSPECTS}

This paper explores the current pressures applied on water resources in the Vaud canton and how they could evolve by the 2060 horizon under climatic and anthropogenic changes. Currently, no pressures are applied on water resources in eastern catchments and this should remain likewise by the medium term. However, over the Broye catchment, one-third of the currently irrigated areas are located upstream the available gauging station. Pressures applied on water resources downstream might then be higher than shown in this study. In opposition, western catchments experience moderate water stress during the summer months due to high urban water needs, especially over the Promenthouse, and high irrigation water needs, especially over the Aubonne, Venoge and Talent catchments. Severe water stress can even be noted in July and August over the Venoge and Talent catchments. By the 2060 horizon, western catchments should experience high to severe water stress from June to August. The Venoge and Talent catchments should be the most vulnerable to water stress as water needs could exceed $80 \%$ of their available freshwater resources during 3 to 4 months. These evolution can be attributed to both hydro-climatic and anthropogenic changes. Indeed, by the 2060 horizon, 
water resources availability should evolve towards earlier high flow peaks and more intense and severe low flows due to a higher fraction of liquid to solid precipitation and thus less snowmelt necessary to support low flows. In addition, water needs should significantly increase in the Lake Geneva region and over the Swiss Plateau mainly due to growing urban water needs but also higher irrigation water needs in the Aubonne, Venoge and Talent catchments.

This study aims at providing a first cantonal vision of water resources vulnerability to climatic and anthropogenic changes. It focuses on a time-horizon poorly explored in mountainous region as most significant hydro-climatic changes are identified in the long-term [e.g. CH2011, 2011; Köplin et al., 2012]. However, our results highlight that significant changes should already be visible in the 2060 horizon, with strong effects on water resources availability. Moreover, few studies have focused on Western Switzerland probably due to its water-rich character and its lack of water conflicts until the droughts of 2003 and 2011. For this first analysis, this study relied on an integrated model that was originally developed over the Mediterranean basin [Milano et al., 2013]. Some modifications were applied to fit to the Swiss context. The initial conceptual rainfall-runoff model was changed for a semi-distributed process-oriented hydrological model in order to better take into account the specificities of mountain hydrological processes. It was also decided to include livestock water use and to explore water stress at a monthly time-step rather than on an annual basis. The operability of the initial framework in a different context shows that it is an easy-to-use method that can be easily adapted and transferred to other geographic areas. Required inputs also seem to be available and accessible datasets. Moreover, the chosen hydrological model PREVAH is often used in Swiss studies to explore the impacts of climate change on water resources [e.g. Gurtz et al. 2003; Köplin et al., 2012]. However, a calibration-validation procedure was here applied for all catchments in opposition to a regionalization process in the original version. The appropriate performance of the model highlights that the model is also suitable to address freshwater availability and thus water stress and water allocation issues.

However, assumptions and uncertainties that frame the study must be addressed. The latter involve every step of the method. Regarding climatic scenarios, the main uncertainty comes from the GCM-RCM model chains [e.g. Kay et al., 2009; Addor et al., 2014]. RCMs are useful tools to consider the impacts of local topography on atmospheric processes yet they operate under boundary conditions set by GCMs and are unable to correct any biases deriving from it [Rummukainen, 2010]. In order to account for this uncertainty, climate change and its impacts on water resources and water stress were explored according to ten GCMRCM model chains. It has the advantage of presenting a range of possible futures. Different practical tips were here used to present concise results. Another uncertainty comes from the hydrological model and its capacity to represent hydrological variations. In this study, three statistical criteria were used to calibrate the model for which good results were found. It is nonetheless assumed that the past rainfall-runoff relationship and any bias identified over the reference period will remain stable in the future. Further limits come from the estimation of water needs. Past trends in livestock farming and demographic growth were extrapolated by the medium-term, and irrigated crops areas were assumed to remain stable. The crop coefficient approach used also tend to overestimate irrigation water needs as it assumes no limitations on crop growth or evapotranspiration. Such approaches are commonly used and are considered robust enough to identify areas where tensions are most likely to occur [e.g. Menzel and Matovelle, 2010; Milano et al., 2013]. However, water needs often depend on factors relying outside the water sector, like policies, tourism economy and trade characteristics [Price, 1992; Fernandez et al., 2014]. To cope with this limit, Grouillet et al. [2015] suggest analyzing the historical evolution of past water demands in order to identify the main factors affecting the temporal dynamics of water needs and thus better implement socio-economic changes in future estimates. Finally, a strong assumption that frames our study is that water needs are only supplied by continental waters. Lake and groundwater pumping were not considered although they fulfilled $22 \%$ and $13 \%$, respectively, of the canton's water needs in the past decade [SGWA, 2004]. Water stress in the Lake Geneva region might then have been overestimated.

Therefore, these limits call for broader impact studies addressing in more detail the water resources actually used, considering local water supply networks, and exploring alternative water use scenarios notably at the catchment scale. Further studies could also explore irrigation water requirements under dry conditions. However, this would require further correction of climatic scenarios in Switzerland as the current delta change method is appropriate to analyze volume and seasonal variations but is inappropriate to explore extreme events [Ruelland et al., 2012; Raggetti et al., 2013]. Finally, due to its high agricultural activities, 
the Vaud canton is subject to water quality issues. To provide a complete overview of water stress issues in the canton, both water availability and water quality should be considered.

\section{ACKNOWLEDGEMENTS}

The authors would like to acknowledge the Federal Office for Environment, the Federal Statistical Office and the Federal Office for Meteorology and Climatology (MeteoSwiss) for providing the necessary input data for both hydrological modeling and water needs evaluation. They would also like to acknowledge the Center for Climate Systems Modeling (C2SM) for delivering the CH2011 future climatic data. The authors are also grateful to Philippe Hohl from the Vaud canton administration and Joseph Mastrullo from the MandaTerre association for providing all the necessary reports and datasets to address water needs.

\section{REFERENCES}

Addor N., Rössler O., Köplin N., Huss M., Weingartner R., Seibert J. (2014). - Robust changes and sources of uncertainty in the projected hydrological regimes of Swiss catchments. Water Resour. Res., 50(10): 7541-7562.

Allen R.G., Pereira L.S., Raes D., Smith M. (1998). - Crop evapotranspiration - guidelines for computing crop water requirements. FAO Irrigation and drainage paper 56, $300 \mathrm{pp}$.

Bergström S. (1976). - Development and application of a conceptual runoff model for Scandinavian catchments. Bulletin Series, A(52): 1-134.

Bosshard T., Kotlarski T., Ewen T., Schär C. (2011). - Spectral representation of the annual cycle in the climate change signal. Hydrol. Earth Syst. Sci., 15: 2777-2788.

CH2011 (2011) Swiss Climate Change Scenarios CH2011. Zurich: C2SM, MeteoSwiss, ETH, NCCR Climate and OcCC, $88 \mathrm{pp}$.

Collier R., Lillywhite R. (2011). - Final report on livestock (University of Warwick). In: Identification and knowledge transfer of novel and emerging technology with the potential to improve water use efficiency within English and Welsh agriculture. Defra Project WU0123. 14 pp. http://www2.warwick.ac.uk/fac/sci/lifesci/wcc/research/resources/wateruse/technology/ (Accessed March 2015).

Fernandez S., Bouleau G., Treyer S. (2014). - Bringing politics back into water planning scenarios in Europe. J. Hydrol., 518: 17-27.

FOSD-ARE - Federal Office for Spatial Development (2013). - Geographical distribution of the Swiss population ("Facts and Figures" series). http://www.are.admin.ch/dokumentation/01378/04466/index.html?lang=fr. (accessed January 2015) (In French).

Frenken K., Gillet V. (2012). - Irrigation water requirement and water withdrawal by country. AQUASTAT report, Food and Agriculture Organization of the United nations (FAO). http://www.fao.org/nr/water/aquastat/water_use agr/IrrigationWaterUse.pdf. $263 \mathrm{pp}$.

FSO - Federal Statistical Office (2003). - GEOSTAT Database Products. Licence No. G158000315, CSFSO, Neuchâtel.

FSO - Federal Statistical Office (2006). - Agriculture in the Swiss cantons. Results from the regional accounts of 2005. Neuchâtel: FSO. 34 pp. (in French).

FSO - Federal Statistical Office (2013a). - Farming businesses, utilized agricultural areas and animals from 1975 to 2013 at the cantonal and commune level. www.bfs.admin.ch (Accessed March 2015).

FSO - Federal Statistical Office (2013b). - Resident population census from 1970 to 2012. www.bfs.admin.ch (Accessed March 2015).

Fündel F., Jörg-Hess S., Zappa M. (2013). - Monthly hydrometeorological ensemble prediction of streamflow droughts and corresponding drought indices. Hydrol. Earth Syst. Sci., 17: 395-407.

Grouillet B., Fabre J., Ruelland D., Dezetter A. (2015). - Historical reconstruction and 2050 projections of water demand under anthropogenic and climate changes in two contrasted Mediterranean catchments. $J$. Hydrol., 522: 684-696. 
Gurtz J., Zappa M., Jasper K., Lang H., Verbunt M., Badoux A., Vitvar T. (2003). - A comparative study in modelling runoff and its components in two mountainous catchments. Hydrol. Process., 17: 297-311.

Kay A.L., Davies H.N., Bell V.A., Jones R.G. (2009). - Comparison of uncertainty sources for climate change impacts: flood frequency in England. Clim. Change, 92: 41-63.

Köplin N., Schädler B., Viviroli D., Weingartner R. (2012). - Relating climate change signals and physiographic catchment properties to clustered hydrological response types. Hydrol. Earth. Syst. Sci., 16: 2267-2283.

MandaTerre (2013). - Diagnosis of irrigation water needs in the Vaud canton. Report established for the "Service du développement territorial du canton de Vaud". 42 pp. (in French).

Menzel L., Matovelle A. (2010). - Current state and future development of blue water availability and blue water demand: a view at seven case studies. J. Hydrol., 384: 245-263.

MeteoSwiss (2008). - Time series of meteorological variables. Zurich: Federal Office for Meteorology and Climatology. www.meteoswiss.admin.ch (Accessed Januray 2015).

Milano M., Ruelland D., Fernandez S., Dezetter A., Fabre J., Servat E., Fritsch J.-M., Ardoin-Bardin S., Thivet G. (2013). - Current state of Mediterranean water resources and future trends under climatic and anthropogenic changes. Hydrol. Sciences J., 58(3): 498-518.

Milano M., Reynard E., Köplin N., Weingartner R. (2015a). - Future trends in hydrological regimes in Western Switzerland. J. Hydrol. (submit.).

Milano M., Reynard E., Köplin N., Weingartner R. (2015b). - Climatic and anthropogenic changes in Western Switzerland: impacts on water stress. Sci. Total Environ. (submit).

Nash J.E., Sutcliffe J.V. (1970). - River flow forecasting through conceptual models, a discussion of principles. J. Hydrol., 10: 282-290.

OcCC - Organe consultatif sur les changements climatiques (2008). - Climate change is a fact - and now? The IPCC report and its consequences for Switzerland. Bern: OcCC. 47 pp. (in French and German)

Price M.F. (1992). - Patterns of the development of tourism in mountain environments. GeoJournal, 27: 87-96.

Ragettli S., Pellicciotti F., Bordoy R., Immerzeel W. (2013). - Sources of uncertainty in modeling the glacio-hydrological response of a karakoram watershed to climate change. Water Resour Res 49: 1-19.

Ruelland D., Ardoin-Bardin S. Collet L., Roucou P. (2012). - Simulating future trens in hydrological regime of a large Sudano-Sahelian catchment under climate change. J. Hydrol 424-425: 207-216.

Rummukainen M. (2010). - State-of-the-art with regional climate models. Clim. Change, 1: 82-96.

Sautier J.-L. (2004). - Water supply in the « Parc jurassien vaudois ». Géomatique Suisse : géoinformation et gestion du territoire, 102(6): 355-357. (in French).

Schmidli J., Frei C. (2005). - Trends of heavy precipitation and wet and dry spells in Switzerland during the 20th century. Int. J. Climatol., 25(6): 753-771.

Serquet G., Marty C., Dulex J.-P., Rebetez M. (2011). - Seasonal trends and temperatures dependence of the snowfall/precipitation-day ratio in Switzerland. Geophys. Res. Lett., 38: L07703. 5 pp.

SGWA - Swiss Gas and Water Industry Association (2004) Water Distribution Data. www.qualitedeleau.ch (Accessed March 2015).

SGWA - Swiss Gas and Water Industry Association (2013). - Statistical results of water dispensers in Switzerland. Year 2012. Zurich: SGWA. 35 pp. (in French).

Shiklomanov I.A. (1991). - The World's water resources. In Proc. Int. Symp. to commemorate 25 Years of the IHP. Paris: UNESCO/IHP, 93-126.

Statistique Vaud (2011). - Population perspectives 2010-2040. Vaud and its regions. Lausanne: SCRIS. 54 pp. (in French).

Viviroli D., Zappa M., Gurtz J., Weingartner R. (2009). - An introduction to the hydrological modelling system PREVAH and its pre- and post- processing-tools. Environ. Model. Software, 24: 1209-1222.

Vullioud P. (2005). - Crop rotation. $3^{\text {rd }}$ Edition. Revue Suisse d'agriculture, 37(4). 3 pp.

Ward D., McKague K. (2007). - Water requirements of livestock. Factsheet Order No. 07-023. Ontario Ministry of Agriculture, Food and Rural Affairs, 7 pp. 